CrossMark

\& click for updates

Cite this: Dalton Trans., 2014, 43 15779

Received 24th July 2014

Accepted 2nd September 2014

DOI: $10.1039 / c 4 d t 02258 \mathrm{k}$

www.rsc.org/dalton

\section{A luminescent molecular turnstile $\uparrow$}

\author{
Nicolas Zigon, Patrick Larpent, Abdelaziz Jouaiti, Nathalie Kyritsakas and \\ Mir Wais Hosseini*
}

\begin{abstract}
A molecular turnstile 1 based on a hydroquinone luminescent hinge bearing two divergently oriented pyridyl units behaving as a rotor and equipped with a handle composed of a tridentate coordinating site considered as the stator was synthesized and its structure was studied in the solid state by X-ray diffraction on single crystal. Its dynamic behaviour in solution was investigated by 1- and 2-D NMR experiments which revealed the free rotation of the rotor around the stator. The rotational movement was locked upon addition of $\mathrm{Pd}(॥)$ simultaneously complexed by the tridentate moiety of the stator and one of the two monodentate pyridyl sites of the rotor. Interestingly, whereas the open state of the turnstile was luminescent, for its closed state the emission was quenched by the heavy atom effect of Pd(॥).
\end{abstract}

Controlling intramolecular motions in dynamic systems is a topic of current interest. A variety of molecular architectures undergoing translational or rotational movements has been reported. ${ }^{1-20}$ Among mobile systems designed so far, molecular turnstiles form a particular class of molecules. ${ }^{21}$ For these compounds, composed of a rotor and a stator covalently interconnected, the free rotation of the rotor around the stator may be blocked by the addition of an external effector. Over the last years, we have reported a series of molecular turnstiles based on the porphyrin backbone $e^{22-29}$ or on $\mathrm{Pt}$ (II) organometallic complexes. ${ }^{30-32}$ Recently, we have described a purely organic turnstile with optical reading between its open and closed states. ${ }^{33}$ Continuing our efforts in this area, herein, we report on another molecular turnstile 1 (Scheme 1) for which the open and closed states may be differentiated by their emission property.

The design of the turnstile $\mathbf{1}$ is based on a functionalized hydroquinone backbone known for displaying luminescence. ${ }^{34-36}$ The latter is equipped with two divergently oriented monodentate pyridyl units and covalently connected to a tridentate coordinating site (Scheme 1).

We arbitrarily consider the hydroquinone moiety bearing the two pyridyl units as the rotor and the tridentate site as the stator. The rational behind the choice of the three components of the turnstile is the following. The hydroquinone core as the hinge was chosen for its luminescence property. The mono-

Molecular Tectonic Laboratory, UMR UDS-CNRS 7140, icFRC, University of Strasbourg, Institut Le Bel, 4, rue Blaise Pascal, F-67000 Strasbourg, France. E-mail: hosseini@unistra.fr

$\dagger$ Electronic supplementary information (ESI) available: Characterisation of new compounds, additional excitation and emission spectra and experimental crystallographic data. CCDC 997862. For ESI and crystallographic data in CIF or other electronic format see DOI: $10.1039 / \mathrm{c} 4 \mathrm{dt} 02258 \mathrm{k}$
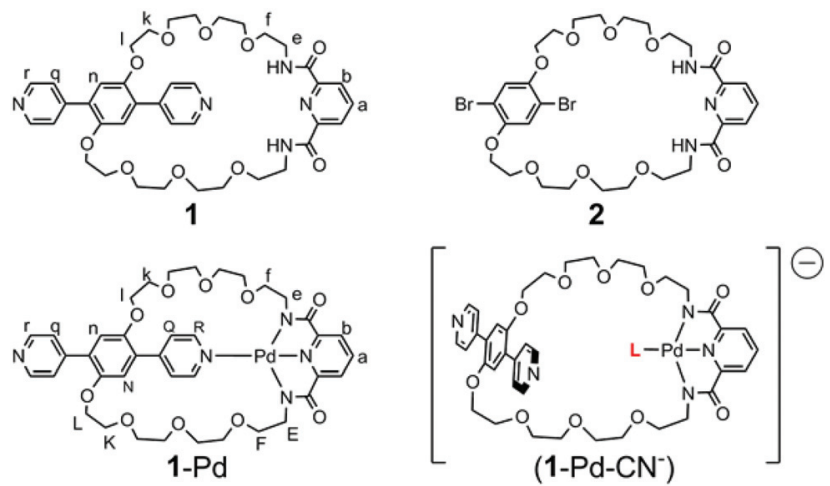

Scheme 1 Structures of compound 1, its precursor 2 and of its Pd complexes 1-Pd and (1-Pd-CN) ${ }^{-}$.

dentate and tridentate sites are introduced in order to lock the rotational movement of the turnstile, i.e. the rotation of the rotor around the stator, through binding of metal cations in the oxidation state II adopting a square planar coordination geometry such as Pd(II) (1-Pd, Scheme 1). The centric nature of the turnstile, i.e. the presence of two pyridyl units connected to the hinge, is justified by synthetic reasons.

For the turnstile in its open state, the rotor freely rotates around the stator (Fig. 1, O1). This intramolecular dynamic behaviour may be blocked by simultaneous binding of the metal centre behaving as an effector by both coordinating sites of the stator and the rotor and thus leading to the closed state of the turnstile (Fig. 1, C). Based on our previous investigation on an analogous system, ${ }^{33}$ whereas the open state of the turnstile should luminesce, its closed state, owing to the heavy atom effect of Pd(II), should be far less emissive. 


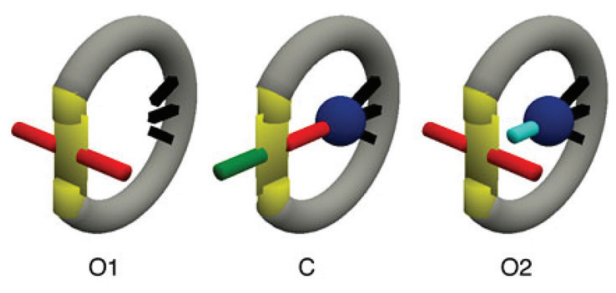

Fig. 1 Schematic representations of the turnstile 1 in its open (O1 and O2) and closed (C) states.

\section{Experimental part}

\section{Characterization techniques}

${ }^{1} \mathrm{H}$ - and ${ }^{13} \mathrm{C}-\mathrm{NMR}$ spectra were recorded at $25{ }^{\circ} \mathrm{C}$ on either Bruker AV 300, AV 500 and AV 600 spectrometers in deuterated solvents $\left(\mathrm{CD}_{2} \mathrm{Cl}_{2}\right)$ and residual solvent peak was used as the internal reference.

Mass spectrometry was performed by the Service de Spectrométrie de Masse, University of Strasbourg.

\section{Single-crystal analysis}

Data were collected at 173(2) $\mathrm{K}$ on a Bruker APEX8 CCD Diffractometer equipped with an Oxford Cryosystem liquid $\mathrm{N}_{2}$ device, using graphite-monochromated Mo-K $\alpha(\lambda=0.71073 \AA)$ radiation. The diffraction data were corrected for absorption. The structure was solved using SHELXS-97 and refined by full matrix least-squares on $F^{2}$ using SHELXL-97. The hydrogen atoms were introduced at calculated positions and not refined (riding model). ${ }^{37}$ CCDC 997862.

Crystal data for 1: $\mathrm{C}_{39} \mathrm{H}_{47} \mathrm{~N}_{5} \mathrm{O}_{10} \cdot \mathrm{CH}_{2} \mathrm{Cl}_{2} \cdot \mathrm{H}_{2} \mathrm{O}, M=848.76$, triclinic, space group $P \overline{1}, a=9.00660(10) \AA, b=13.7975(2) \AA, c=$ $17.5755(2) \AA, \alpha=80.8420(10)^{\circ}, \beta=84.8240(10)^{\circ}, \gamma=79.8220(10)^{\circ}$, $V=2117.97(5) \AA^{3}, T=173(2) \mathrm{K}, Z=2, D_{\mathrm{c}}=1.331 \mathrm{Mg} \mathrm{m}^{-3}, \mu=$ $0.218 \mathrm{~mm}^{-1}, 43643$ collected reflections, 11353 independent $\left(R_{\text {int }}=0.0377\right), \mathrm{GooF}=1.023, R_{1}=0.0470, \mathrm{w} R_{2}=0.1097$ for $I>$ $2 \sigma(I)$ and $R_{1}=0.0756, \mathrm{w} R_{2}=0.1230$ for all data.

\section{Synthesis}

Compound 1. To a toluene $(10 \mathrm{~mL})$ solution of compound $2^{33}$ (250 mg, $0.33 \mathrm{mmol}, 1 \mathrm{eq}$.), a $\mathrm{MeOH}(5 \mathrm{~mL}$ ) solution of 4-pyridylboronic acid (164 mg, $1.33 \mathrm{mmol}, 4$ eq.) and an aqueous solution of $\mathrm{Na}_{2} \mathrm{CO}_{3}(2 \mathrm{M}, 6 \mathrm{~mL})$ were successively added. The mixture was degassed before $\mathrm{Pd}\left(\mathrm{PPh}_{3}\right)_{4}$ (76 mg, $0.07 \mathrm{mmol}, 0.2$ eq.) was added. The biphasic mixture was heated at $80{ }^{\circ} \mathrm{C}$ for $24 \mathrm{~h}$. The solvents were removed under reduced pressure and the resulting solid was partitioned between $\mathrm{CH}_{2} \mathrm{Cl}_{2}(100 \mathrm{~mL})$ and a $10 \% \mathrm{NaHCO}_{3}$ aqueous solution $(100 \mathrm{~mL})$. The organic phase was collected and further washed with a $10 \% \mathrm{NaHCO}_{3}$ aqueous solution $(2 \times 100 \mathrm{~mL})$ and dried over $\mathrm{MgSO}_{4}$. After evaporation of the solvent, column chromatography $\left(\mathrm{SiO}_{2}, \mathrm{CH}_{2} \mathrm{Cl}_{2}-\mathrm{MeOH} 99 / 1\right.$ to 90/10) afforded the desired compound $\mathbf{1}$ as a yellow solid $(220 \mathrm{mg}$, $0.29 \mathrm{mmol}, 88 \%) .{ }^{1} \mathrm{H}-\mathrm{NMR}\left(\mathrm{CD}_{2} \mathrm{Cl}_{2}, 600 \mathrm{MHz}\right): \delta(\mathrm{ppm})=2.80$ (br, $\left.2 \mathrm{H}, \mathrm{H}_{2} \mathrm{O}\right), 3.42\left(\mathrm{~m}, 4 \mathrm{H}, \mathrm{H}_{\mathrm{e}}\right), 3.49\left(\mathrm{~m}, 8 \mathrm{H}, \mathrm{OCH}_{2}\right), 3.54(\mathrm{~m}$, $\left.4 \mathrm{H}, \mathrm{OCH}_{2}\right), 3.58\left(\mathrm{~m}, 4 \mathrm{H}, \mathrm{OCH}_{2}\right), 3.61\left(\mathrm{~m}, 4 \mathrm{H}, \mathrm{OCH}_{2}\right), 3.74(\mathrm{~m}$, $\left.4 \mathrm{H}, \mathrm{H}_{\mathrm{k}}\right), 4.19\left(\mathrm{~m}, 4 \mathrm{H}, \mathrm{H}_{\mathrm{l}}\right), 7.23\left(\mathrm{~s}, 2 \mathrm{H}, \mathrm{H}_{\mathrm{n}}\right), 7.68\left(\mathrm{~d}, 4 \mathrm{H}, \mathrm{H}_{\mathrm{q}},{ }^{3} J=\right.$ $5.7 \mathrm{~Hz}), 8.00\left(\mathrm{t}, 1 \mathrm{H}, \mathrm{H}_{\mathrm{a}},{ }^{3} J=7.7 \mathrm{~Hz}\right), 8.28\left(\mathrm{~d}, 2 \mathrm{H}, \mathrm{H}_{\mathrm{b}},{ }^{3} J=\right.$ $7.7 \mathrm{~Hz}$ ), 8.70 (br, 4H, $\mathrm{H}_{\mathrm{r}}$ ), 9.07 (br t, $2 \mathrm{H}, \mathrm{NH},{ }^{3} J=5.8 \mathrm{~Hz}$ ). ${ }^{13} \mathrm{C}-\mathrm{NMR}$ HSQC-HMBC $\left(\mathrm{CDCl}_{3}, 125 \mathrm{MHz}\right): \delta(\mathrm{ppm})=39.5\left(\mathrm{C}_{\mathrm{e}}\right)$, 69.9, 69.9, 70.2, 70.4, 70.7, 70.8, 71.1, $117.1\left(\mathrm{C}_{\mathrm{n}}\right), 124.5\left(\mathrm{C}_{\mathrm{q}}\right.$ or $\left.\mathrm{C}_{\mathrm{b}}\right), 124.8\left(\mathrm{C}_{\mathrm{q}}\right.$ or $\left.\mathrm{C}_{\mathrm{b}}\right), 129.4\left(\mathrm{C}_{\mathrm{p}}\right), 138.7\left(\mathrm{C}_{\mathrm{a}}\right), 145.9\left(\mathrm{C}_{\mathrm{c}}\right), 149.1$ $\left(\mathrm{C}_{\mathrm{o}}\right), 149.8\left(\mathrm{C}_{\mathrm{r}}\right), 151.0\left(\mathrm{C}_{\mathrm{m}}\right), 164.3\left(\mathrm{C}_{\mathrm{d}}\right)$. UV-Vis $\left(\mathrm{CH}_{2} \mathrm{Cl}_{2}\right): \lambda_{\max }$ $(\log \varepsilon)=274$ (4.31), 335 (3.90). MS (ESI): $m / z$ calcd for $\mathrm{C}_{39} \mathrm{H}_{48} \mathrm{~N}_{5} \mathrm{O}_{10}{ }^{+}[\mathrm{M}+\mathrm{H}]^{+} 746.34 \mathrm{~g} \mathrm{~mol}^{-1}$; found $746.36 \mathrm{~g} \mathrm{~mol}^{-1}$.

Compound 1-Pd. To a $1 / 1 \mathrm{CH}_{2} \mathrm{Cl}_{2}-\mathrm{CH}_{3} \mathrm{CN}$ solution $(40 \mathrm{~mL})$ of compound 1 (40 mg, $54 \mu \mathrm{mol}, 1$ eq.) $\mathrm{Pd}(\mathrm{OAc})_{2}(13 \mathrm{mg}$, $59 \mu \mathrm{mol}, 1.1$ eq.) in $\mathrm{CH}_{3} \mathrm{CN}(1 \mathrm{~mL})$ was added dropwise. After stirring at RT for $24 \mathrm{~h}$, the solution was first filtrated over $\mathrm{SiO}_{2}$ $\left(\mathrm{CH}_{2} \mathrm{Cl}_{2}-\mathrm{MeOH} 90 / 10\right)$ and then purified by preparative thin layer chromatography $\left(\mathrm{SiO}_{2}, \mathrm{CHCl}_{3}-\mathrm{MeOH} 95 / 5\right)$ affording the complex 1-Pd as a yellow solid (31 mg, $36 \mu \mathrm{mol}, 69 \%) .{ }^{1} \mathrm{H}-\mathrm{NMR}$ $\left(\mathrm{CD}_{2} \mathrm{Cl}_{2}, 600 \mathrm{MHz}\right): \delta(\mathrm{ppm})=3.00\left(\mathrm{t}, 2 \mathrm{H}, \mathrm{H}_{\mathrm{e}}\right.$ or E,$\left.{ }^{3} J=5.4 \mathrm{~Hz}\right)$, $3.12\left(\mathrm{t}, 2 \mathrm{H}, \mathrm{H}_{\mathrm{e}}\right.$ or $\left.\mathrm{E},{ }^{3} J=5.4 \mathrm{~Hz}\right), 3.50\left(\mathrm{~m}, 4 \mathrm{H}, \mathrm{H}_{\mathrm{f} \text { or } \mathrm{F}}+\mathrm{OCH}_{2}\right)$, $3.61\left(\mathrm{~m}, 4 \mathrm{H}, \mathrm{H}_{\mathrm{f} \text { or } \mathrm{F}}+\mathrm{OCH}_{2}\right), 3.64-3.73\left(\mathrm{~m}, 12 \mathrm{H}, \mathrm{OCH}_{2}\right), 3.75$ $\left(\mathrm{m}, 2 \mathrm{H}, \mathrm{H}_{\mathrm{K}}\right), 3.85\left(\mathrm{~m}, 2 \mathrm{H}, \mathrm{H}_{\mathrm{k}}\right), 4.27\left(\mathrm{~m}, 4 \mathrm{H}, \mathrm{H}_{1+\mathrm{L}}\right), 7.00(\mathrm{~s}, 1 \mathrm{H}$, $\left.\mathrm{H}_{\mathrm{n}}\right), 7.52\left(\mathrm{~d}, 2 \mathrm{H}, \mathrm{H}_{\mathrm{q}},{ }^{3} J=6.1 \mathrm{~Hz}\right), 7.66\left(\mathrm{~d}, 2 \mathrm{H}, \mathrm{H}_{\mathrm{b}},{ }^{3} J=7.8 \mathrm{~Hz}\right)$, $7.77\left(\mathrm{~s}, 1 \mathrm{H}, \mathrm{H}_{\mathrm{N}}\right), 8.02\left(\mathrm{t}, 1 \mathrm{H}, \mathrm{H}_{\mathrm{a}},{ }^{3} J=7.8 \mathrm{~Hz}\right), 8.10\left(\mathrm{~d}, 2 \mathrm{H}, \mathrm{H}_{\mathrm{Q}}\right.$, $\left.{ }^{3} J=6.8 \mathrm{~Hz}\right), 8.64\left(\mathrm{br} \mathrm{d}, 2 \mathrm{H}, \mathrm{H}_{\mathrm{r}},{ }^{3} J=5.3 \mathrm{~Hz}\right), 9.12\left(\mathrm{~d}, 2 \mathrm{H}, \mathrm{H}_{\mathrm{R}}\right.$, $\left.{ }^{3} J=6.7 \mathrm{~Hz}\right) \cdot{ }^{13} \mathrm{C}-\mathrm{NMR}$ HSQC-HMBC $\left(\mathrm{CD}_{2} \mathrm{Cl}_{2}, 125 \mathrm{MHz}\right)$ : $\delta(\mathrm{ppm})=46.9\left(\mathrm{C}_{\mathrm{e}}\right.$ or $\left.\mathrm{E}\right), 47.3\left(\mathrm{C}_{\mathrm{e}}\right.$ or $\left.\mathrm{E}\right), 69.0,69.6,70.9,71.2$, 71.2, 71.3, 71.4, 71.5, 71.7, 72.0, 72.3, 111.4, $115.3\left(\mathrm{C}_{\mathrm{n}}\right), 119.2$, $119.7\left(\mathrm{C}_{\mathrm{N}}\right), 124.1\left(\mathrm{C}_{\mathrm{b}+\mathrm{B} \text { or } \mathrm{q}}\right), 124.2\left(\mathrm{C}_{\mathrm{b}+\mathrm{B} \text { or } \mathrm{q}}\right), 126.0\left(\mathrm{C}_{\mathrm{Q}}\right), 126.1$, 130.4, 132.3, $140.8\left(\mathrm{C}_{\mathrm{a}}\right), 142.8,148.4\left(\mathrm{C}_{\mathrm{m} \text { or }} \mathrm{M}\right), 151.2\left(\mathrm{C}_{\mathrm{r}}\right), 151.6$ $\left(\mathrm{C}_{\mathrm{m} \text { or M }}\right), 152.9\left(\mathrm{C}_{\mathrm{R}}\right), 153.1\left(\mathrm{C}_{\mathrm{c}}\right.$ or $\left.\mathrm{C}\right), 171.3\left(\mathrm{C}_{\mathrm{d}}\right.$ or $\left.\mathrm{D}\right), 171.4$ $\left(\mathrm{C}_{\mathrm{d} \text { or D }}\right)$. UV-Vis $\left(\mathrm{CH}_{2} \mathrm{Cl}_{2}\right): \lambda_{\max }(\log \varepsilon)=249$ (4.29), 282 (4.42), 348 (4.18). MS (ESI): $m / z$ calcd for $\mathrm{C}_{39} \mathrm{H}_{46} \mathrm{~N}_{5} \mathrm{O}_{10} \mathrm{Pd}^{+}[\mathrm{M}+\mathrm{H}]^{+}$ $850.23 \mathrm{~g} \mathrm{~mol} \mathrm{~m}^{-1}$; found $850.23 \mathrm{~g} \mathrm{~mol}^{-1}$; $\mathrm{m} / \mathrm{z}$ calcd for $\mathrm{C}_{117} \mathrm{H}_{136} \mathrm{~N}_{15} \mathrm{O}_{30} \mathrm{Pd}_{3} \mathrm{Na}^{2+}[3 \mathrm{M}+\mathrm{Na}+\mathrm{H}]^{+} 1286.83 \mathrm{~g} \mathrm{~mol}^{-1}$; found $1286.41 \mathrm{~g} \mathrm{~mol}^{-1} ; \mathrm{m} / z$ calcd for $\mathrm{C}_{39} \mathrm{H}_{46} \mathrm{~N}_{5} \mathrm{O}_{10} \mathrm{PdNa}^{2+}[\mathrm{M}+\mathrm{Na}+$ $\mathrm{H}]^{2+} 437.61 \mathrm{~g} \mathrm{~mol}^{-1}$; found $437.22 \mathrm{~g} \mathrm{~mol}^{-1}$.

\section{Results}

The turnstile 1 was prepared in 8 steps. The precursor macrocyclic compound 2 was obtained in $90 \%$ yield as previously described. ${ }^{33}$ The turnstile 1 was obtained in $88 \%$ yield by coupling 4-pyridyl boronic acid with compound 2 in the presence of $\mathrm{Pd}\left(\mathrm{PPh}_{3}\right)_{4}$. The closed state of turnstile 1-Pd was obtained in $69 \%$ yield upon metallation by $\mathrm{Pd}(\mathrm{OAc})_{2}$.

The turnstile 1 was characterized both in solution by NMR spectroscopy and in the solid state by X-ray diffraction on single crystal (Fig. 2, see Experimental section). Single crystals of 1 were obtained at $25{ }^{\circ} \mathrm{C}$ upon slow diffusion of cyclohexane into a $\mathrm{CH}_{2} \mathrm{Cl}_{2}$ solution of 1 .

Compound 1 crystallizes (triclinic $P \overline{1}$ ) with $\mathrm{CH}_{2} \mathrm{Cl}_{2}$ and $\mathrm{H}_{2} \mathrm{O}$ molecules. The $\mathrm{C}-\mathrm{C}, \mathrm{C}-\mathrm{O}$ and $\mathrm{C}-\mathrm{N}$ distances are within the expected range. The two amide groups $\left(d_{\mathrm{C}=\mathrm{O}}\right.$ of 1.230 and $1.226 \AA$ ) are almost coplanar with the pyridyl unit of the tridentate chelate (tilt angles of -2.162 and $4.373^{\circ}$ ). The two pyridyl units connected to the hydroquinone moiety are tilted 


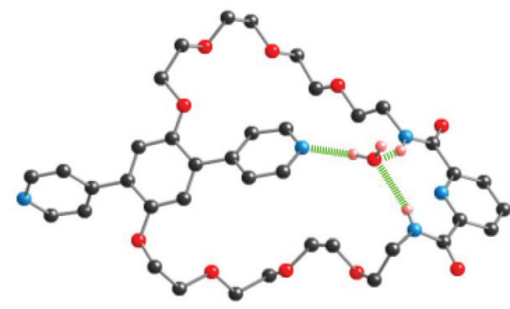

Fig. 2 X-Ray structure of 1 . Green dashed lines indicate H-bonds between the water molecule and the turnstile. $\mathrm{H}$ atoms, except those involved in $\mathrm{H}$-bonds, and $\mathrm{CH}_{2} \mathrm{Cl}_{2}$ solvent molecules are omitted for clarity. For bond distances and angles see text.

by -39.30 and $-50.21^{\circ}$ with respect to the central aryl unit. The water molecule is located between the tridentate moiety of the stator and one of the two pyridyl units of the rotor. The $\mathrm{H}_{2} \mathrm{O}$ molecule behaves both as a $\mathrm{H}$-bond acceptor towards the two $\mathrm{NH}$ groups of the amide moieties ( $\mathrm{NH} \cdots \mathrm{O}$ distances of 2.362 and $2.220 \AA$ and $\mathrm{NHO}$ angles of 150.84 and $148.97^{\circ}$ ) and as a single $\mathrm{H}$-bond donor towards the pyridyl moiety of the rotor $\left(\mathrm{OH} \cdots \mathrm{N}_{\text {py }}\right.$ distance of $2.041 \AA$ and $\mathrm{OHN}$ angle of $\left.172.60^{\circ}\right)$.

The dynamic behaviour of the turnstile $\mathbf{1}$ in solution in $\mathrm{CD}_{2} \mathrm{Cl}_{2}$ was studied at $25{ }^{\circ} \mathrm{C}$ by 1 - and 2-D NMR spectroscopy which allowed to assign all $\mathrm{H}$ atoms (Scheme 1). In the aromatic region of the ${ }^{1} \mathrm{H}-\mathrm{NMR}$ spectrum of $\mathbf{1}$ (Fig. 3a), the signal at $7.23 \mathrm{ppm}$ corresponding to $\mathrm{H} n$ appears as a unique singlet whereas signals corresponding to $\mathrm{H} q$ and $\mathrm{H} r$ at 7.68 and $8.70 \mathrm{ppm}$ respectively appear as two signals (see Scheme 1 for assignment). These observations imply the equivalence between the two halves of the rotor and therefore the rotation of the rotor inside the stator, defining thus the open state $\mathrm{O} 1$ of the turnstile (Fig. 1).

Addition of Pd(II) leading to 1-Pd (closed state C, Fig. 1) results from the simultaneous binding of the cation by both the tridentate site of the stator and one of the two monodentate pyridyl sites of the rotor (Fig. 3b). As expected, the complexation process leads to the disappearance of the $\mathrm{NH}$ signals at $9.07 \mathrm{ppm}$, the shift of all aromatic signals and the splitting of the signals corresponding to the two pyridyl units belonging to the rotor.

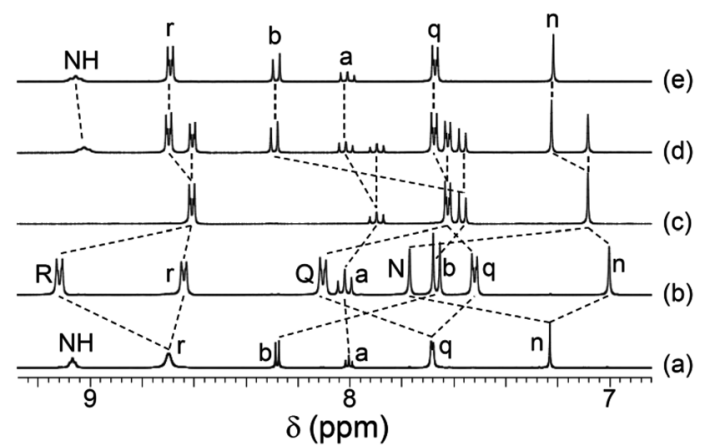

Fig. 3 Portions of ${ }^{1} \mathrm{H}-\mathrm{NMR}\left(\mathrm{CD}_{2} \mathrm{Cl}_{2}, X 00 \mathrm{MHz}, X=6\right.$ for a and $X=3$ for b-e, $298 \mathrm{~K}$ ): (a) turnstile 1, (b) 1-Pd, (c) 1-Pd + 1 eq. of TBACN, (d) 1-Pd + 3 eq. of TBACN, (e) 1-Pd + excess of TBACN. For signals assignment see Scheme 1.
Indeed, upon binding to $\mathrm{Pd}(\mathrm{II})$, the two pyridyl units are differentiated leading to $\mathrm{H} n, \mathrm{H} q$ and $\mathrm{H} r$ signals for the unbound and $\mathrm{HN}, \mathrm{HQ}$ and $\mathrm{H} R$ signals corresponding to the coordinated pyridyl moieties. Furthermore, $\mathrm{H} a$ and $\mathrm{H} b$ signals corresponding to the pyridyl moiety of the chelating unit undergo noticeable shifts ( $\Delta \delta$ of 0.02 and -0.62 ppm respectively). Both the open and closed states of the turnstile have been investigated by $2 \mathrm{D}{ }^{1} \mathrm{H}-{ }^{1} \mathrm{H}$ NOESY experiments (Fig. 4).

For the turnstile $\mathbf{1}$ in its open state, as expected correlations between chemically connected hydrogen atoms such as $\mathrm{H} n$ / $\mathrm{H} k-l$ and $\mathrm{HNH} / \mathrm{H} e$ and between hydrogen atoms of the pyridyl group of the rotor and those of the polyethylene glycol chain of the stator are observed. Interestingly, the 2D spectrum of 1 displays a cross-relaxation peak between the $\mathrm{H}_{2} \mathrm{O}$ signal at 2.80 ppm and the NH signal at 9.07 ppm (Fig. 4 top). The presence of the water molecule in solution between the stator and the rotor is in agreement with the observation of $\mathrm{H}$ bonds in the solid state and further corroborated by the broadening of $\mathrm{H} q$ and $\mathrm{H} r$ signals. However, the interaction between the water molecule and the two parts of the turnstile, although hindering the free rotation of the rotor around the stator, appears to be insufficient at $25{ }^{\circ} \mathrm{C}$ to lock the rotational movement leading thus to a sufficiently fast oscillation process with respect to the NMR timescale rendering the two pyridyl unit equivalent.

For the turnstile in its closed position 1-Pd, as in the case of 1 discussed above, the expected through space correlations between chemically connected hydrogen atoms such as $\mathrm{H} n-\mathrm{H} l$ and $\mathrm{HN}-\mathrm{H} L$ are observed (Fig. 4 bottom). In contrast with $\mathbf{1}$, owing to the locking of the rotational movement by binding of $\mathrm{Pd}^{2+}$ cation in 1-Pd, only correlations between $\mathrm{HQ}$ and $\mathrm{H} R$
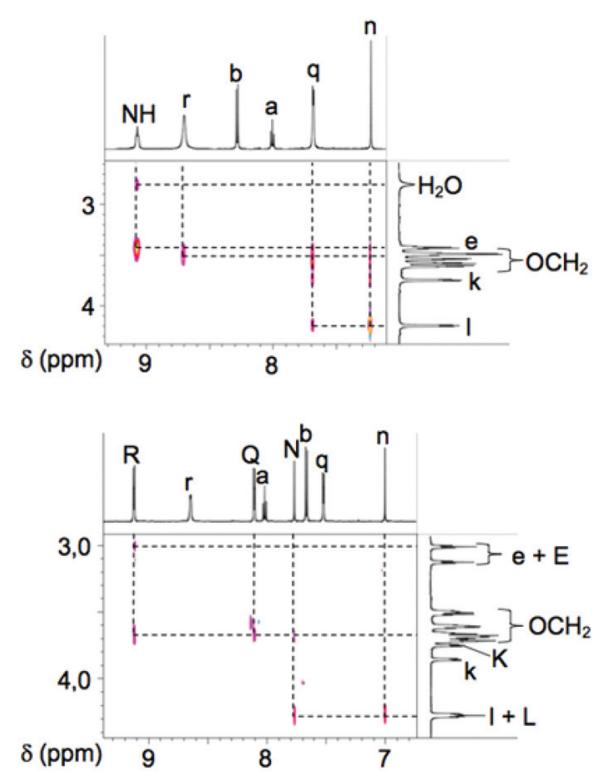

Fig. 4 Portions of the ${ }^{1} \mathrm{H}-{ }^{1} \mathrm{H}$ NOESY correlation maps $\left(\mathrm{CD}_{2} \mathrm{Cl}_{2}, 298 \mathrm{~K}\right.$, $500 \mathrm{MHz}$ ) of the turnstile 1 in its open state (top) and in its closed state 1-Pd (bottom) showing through space correlations between the aromatic moieties and the oligoethylene glycol chain. 
atoms of the bound pyridyl unit belonging to the rotor and the $\mathrm{OCH}_{2} \mathrm{H}$-atoms of the handle are observed (Fig. 4 bottom).

The switching between the closed state $\mathrm{C}$ and open state $\mathrm{O} 2$ (Scheme 1) was achieved using $\mathrm{CN}^{-}$anion, a stronger ligand than the pyridyl unit of the rotor. The addition of 1 eq. of $\mathrm{CN}^{-}$ anions (Fig. 3c) leads to the open state $\mathrm{O} 2(1-\mathrm{Pd}-\mathrm{CN})^{-}$for which the $\mathrm{CN}^{-}$anion replaces the pyridyl unit in 1-Pd. Consequently, as for the open state $\mathrm{O} 1$ of the turnstile, the free rotation of the rotor around the stator renders the two pyridyl moieties equivalent thus giving rise to only three sets of signals (singlet for $\mathrm{H} n$ and two doublets for $\mathrm{H} q$ and $\mathrm{H} r$ ). Furthermore, the shift observed for $\mathrm{H} a$ and $\mathrm{H} b$ signals and the absence of signal corresponding to $\mathrm{NH}$ groups indicate that the $\mathrm{Pd}(\mathrm{II})$ cation remains coordinated to the tridentate site of the stator. Further additions of $\mathrm{CN}^{-}$anion (3 eq., Fig. 3d) leads to a mixture of the two open states $\mathrm{O} 1$ and $\mathrm{O} 2$. Finally, in the presence of an excess of $\mathrm{CN}^{-}$anion, the open state $\mathrm{O} 1$ is generated (Fig. 3e).

As stated in the introduction, the turnstile was designed in order to assess its open (1) and closed (1-Pd) states by emission spectroscopy.

The absorption and emission properties of the turnstile in its open (1) and closed (1-Pd) states were studied in solution in $\mathrm{CH}_{2} \mathrm{Cl}_{2}$ at $298 \mathrm{~K}$. For compound 1 , the UV-visible absorption spectra is composed of three bands at $235 \mathrm{~nm}, 274 \mathrm{~nm}(\varepsilon=$ $\left.20.3 \times 10^{3} \mathrm{~L} \mathrm{~mol}^{-1} \mathrm{~cm}^{-1}\right)$ and at $335 \mathrm{~nm}\left(\varepsilon=7.94 \times 10^{3} \mathrm{~L} \mathrm{~mol}^{-1}\right.$ $\mathrm{cm}^{-1}$ ) (Fig. 5). Upon metallation by Pd(II) leading to the closed state 1-Pd, again the same three absorption bands are observed however with bathochromic and hyperchromic shifts $249 \mathrm{~nm}\left(\varepsilon=19.5 \times 10^{3} \mathrm{~L} \mathrm{~mol}^{-1} \mathrm{~cm}^{-1}\right) ; 282 \mathrm{~nm}\left(\varepsilon=26.3 \times 10^{3} \mathrm{~L}\right.$ $\left.\mathrm{mol}^{-1} \mathrm{~cm}^{-1}\right) ; 348 \mathrm{~nm}\left(\varepsilon=15.1 \times 10^{3} \mathrm{~L} \mathrm{~mol}^{-1} \mathrm{~cm}^{-1}\right)$.

Both 1 and 1-Pd emit in the blue part of the visible spectrum at $413 \mathrm{~nm}$ when excited at $350 \mathrm{~nm}$. Their emission spectra are almost identical and the emission wavelength is not affected by metallation indicating that their excited states are similar. However, whereas the turnstile $\mathbf{1}$ in its open state is strongly luminescent when excited at $350 \mathrm{~nm}$, in its closed state 1-Pd, it is far less emissive.

The quantum yields, using quinine sulphate as reference, are $78 \%$ for 1 and $0.60 \%$ for $1-\mathrm{Pd}$. The lifetime of the excited state for 1 and 1-Pd is in the 3.1-3.6 ns range. However, in the case of 1-Pd, a second process with a lifetime of $c a .88$ ps was observed. A plausible explanation could be that, upon excitation in the $\pi-\pi^{*}$ of the 1,4-dipyridylphenyl core, a $S_{1}$ excited

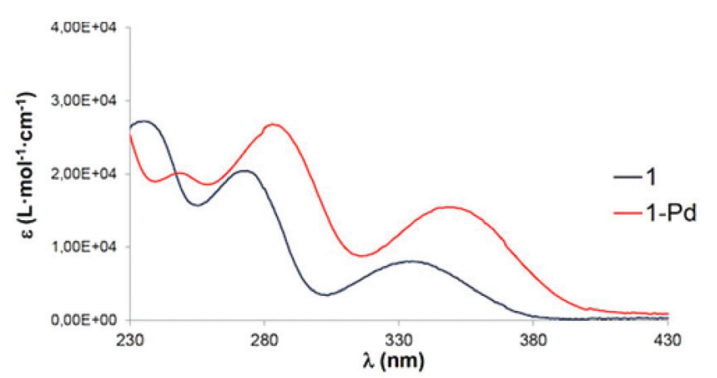

Fig. 5 UV-visible spectra $\left(\mathrm{CH}_{2} \mathrm{Cl}_{2}, 298 \mathrm{~K}\right)$ of 1 (black) and 1-Pd (red). state with a lifetime of $c a .3 .5 \mathrm{~ns}$ is generated. Owing to the heavy atom effect of $\operatorname{Pd}(\mathrm{II})$ located in the proximity of the emitting site, the transition to a $\mathrm{T}_{1}$ excited state is promoted which is subsequently quenched by solvent or $\mathrm{O}_{2}$ molecule.

Interestingly, under the same conditions, for iso-absorbing solutions of 1 or 1-Pd, whereas the open state of the turnstile emits strongly when excited at $350 \mathrm{~nm}$, for the closed state, the emission was found to be below the detection limit of the spectrometer (Fig. 6).

In conclusion, a new molecular turnstile $\mathbf{1}$ based on a luminescent hydroquinone moiety as a hinge was designed and synthesised. The hinge was equipped both with two monodentate pyridyl units and a tridentate coordinating site. The turnstile 1 may be described as a rotor composed of the two pyridyl moieties and the hinge connected to a stator comprising the hinge and the tridentate unit. For the turnstile in its open state, rotor freely rotates inside the stator. This movement may be blocked upon addition of $\mathrm{Pd}(\mathrm{II})$ as an external effector. Indeed, the simultaneous binding of the metal cation by both the tridentate coordinating site of the stator and one of the two monodentate pyridyl groups of the rotor leads to the closed state of the turnstile 1-Pd. The switching between the open and the closed states of the turnstile may be achieved using $\mathrm{CN}^{-}$anion as an auxiliary strong ligand. As a consequence of the design of the turnstile 1 comprising a luminescent hinge, the reading of the open and closed states may be achieved optically. Indeed, whereas the open state of the turnstile is strongly emissive, for its closed state 1-Pd, owing to the heavy atom effect of the cation, the emission process is quenched.

Following the design principle reported here, other turnstiles bearing two different coordinating sites on the rotor are currently under investigation.

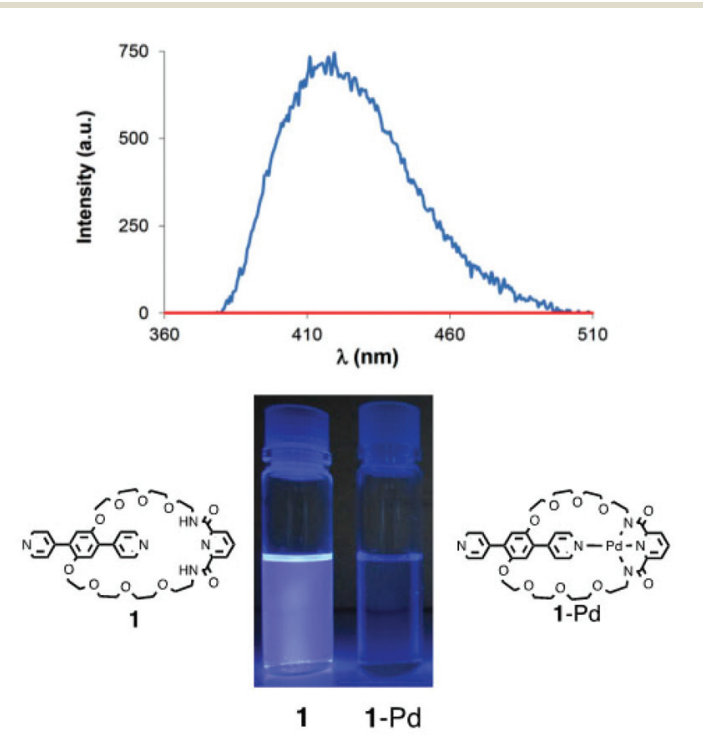

Fig. 6 Emission spectra $\left(\lambda_{\text {exc }}=350 \mathrm{~nm}\right)$ for iso-absorbing solutions of the turnstiles 1 (blue) and 1-Pd (red) in aerated $\mathrm{CH}_{2} \mathrm{Cl}_{2}$ solution at $298 \mathrm{~K}$ (top) and photographs of irradiated $\left(\lambda_{\text {exc }}=365 \mathrm{~nm}\right.$ ) solutions of the turnstile in its open (1) and closed (1-Pd) states. 
Financial supports by the University of Strasbourg, the International Centre for Frontier Research in Chemistry (icFRC), Strasbourg, the Institut Universitaire de France, the CNRS and the Ministry of Education and Research (PhD fellowship to P. L. and N. Z.) are acknowledged.

\section{Notes and references}

1 J.-P. Sauvage, in Molecular machines and motors, Structure and bonding, ed. J.-P. Sauvage, Springer, Berlin, Heidelberg, 2001, vol. 99, pp. 1-282; V. Balzani, M. Venturi and A. Credi, in Molecular devices and machines: a journey into the nanoworld, Wiley-VCH, Weinheim, 2003, pp. 1-457; T. R. Kelly, in Molecular machines, Topics in Current Chemistry, ed. T. R. Kelly, Springer, Berlin, Heidelberg, 2005, vol. 262, pp. 1-227.

2 E. R. Kay, D. A. Leigh and F. Zerbetto, Angew. Chem., Int. Ed., 2007, 46, 72.

3 W. R. Browne and B. L. Feringa, Nat. Nanotechnol., 2006, 1, 25.

4 G. S. Kottas, L. I. Clarke, D. Horinek and J. Michl, Chem. Rev., 2005, 105, 1281.

5 G. Vives, H.-P. Jacquot de Rouville, A. Carella, J.-P. Launay and G. Rapenne, Chem. Soc. Rev., 2009, 38, 1551.

6 V. Balzani, A. Credi, F. M. Raymo and J. F. Stoddart, Angew. Chem., Int. Ed., 2000, 39, 3348.

7 (a) K. Tashiro, K. Konishi and T. Aida, J. Am. Chem. Soc., 2000, 122, 7921; (b) K. Kinbara, T. Muraoka and T. Aida, Org. Biomol. Chem., 2008, 6, 1871.

8 M. Takeuchi, T. Imada and S. Shinkai, Angew. Chem., Int. Ed., 1998, 37, 2096.

9 (a) V. Balzani, M. Gomez-Lopez and J. F. Stoddart, Acc. Chem. Res., 1998, 31, 405; (b) J. F. Stoddart, Acc. Chem. Res., 2001, 34, 410; (c) V. Balzani, A. Credi, F. M. Raymo and J. F. Stoddart, Angew. Chem., Int. Ed., 2000, 39, 3348; (d) A. H. Flood, R. J. A. Ramirez, W.-Q. Deng, R. P. Muller, W. A. Goddard III and J. F. Stoddart, Aust. J. Chem., 2004, 57, 301; (e) C. A. Schalley, K. Beizai and F. Vögtle, Acc. Chem. Res., 2001, 34, 465; $(f)$ A. M. Fuller, D. A. Leigh, P. J. Lusby, I. D. H. Oswald, S. Parsons and D. B. Walker, Angew. Chem., Int. Ed., 2004, 43, 3914; $(g)$ D. A. Leigh, P. J. Lusby, A. M. Z. Slawin and D. B. Walker, Angew. Chem., Int. Ed., 2005, 44, 4557; (h) F. Coutrot and E. Busseron, Chem. - Eur. J., 2009, 15, 5186; (i) E. Busseron, C. Romuald and F. Coutrot, Chem. - Eur. J., 2010, 16, 10062; (j) C. Clavel, C. Romuald, E. Brabet and F. Coutrot, Chem. Eur. J., 2013, 19, 2982.

10 (a) J.-P. Sauvage, Science, 2001, 291, 2105; (b) J.-P. Sauvage, Acc. Chem. Res., 1998, 31, 611; (c) J.-P. Collin, C. DietrichBuchecker, P. Gavina, M. C. Jimenez-Molero and J.-P. Sauvage, Acc. Chem. Res., 2001, 34, 477.

11 (a) T. R. Kelly, H. De Silva and R. A. Silva, Nature, 1999, 401, 150; (b) T. R. Kelly, Acc. Chem. Res., 2001, 34, 514; (c) T. R. Kelly, X. Cai, F. Damkaci, S. B. Panicker, B. Tu, S. M. Bushell, I. Cornella, M. J. Piggott, R. Salives,
M. Cavero, Y. Zhao and S. Jasmin, J. Am. Chem. Soc., 2007, 129, 376.

12 (a) N. Koumura, R. W. J. Zijlstra, R. A. van Delden, N. Harada and B. L. Feringa, Nature, 1999, 401, 152; (b) M. K. J. ter Wiel, R. A. van Delden, A. Meetsma and B. L. Feringa, J. Am. Chem. Soc., 2003, 125, 15076; (c) R. A. van Delden, M. K. J. ter Wiel, N. Koumura and B. L. Feringa, in Molecular Motors, ed. M. Schliwa, WileyVCH, Weinheim, 2003, pp. 559-577.

13 (a) J. F. Morin, Y. Shirai and J. M. Tour, Org. Lett., 2006, 8, 1713; (b) Y. Shirai, J.-F. Morin, T. Sasaki, J. M. Guerrero and J. M. Tour, Chem. Soc. Rev., 2006, 35, 1043; (c) G. Vives and J. M. Tour, Acc. Chem. Res., 2009, 42, 473.

14 (a) L. Grill, K.-H. Rieder, F. Moresco, G. Jimenez-Bueno, C. Wang, G. Rapenne and C. Joachim, Surf. Sci., 2005, 584, L153; (b) U. G. E. Perera, F. Ample, H. Kersell, Y. Zhang, G. Vives, J. Echeverria, M. Grisolia, G. Rapenne, C. Joachim and S.-W. Hla, Nat. Nanotechnol., 2013, 8, 46.

15 I. Pochorovski, M. O. Ebert, J. P. Gisselbrecht, C. Boudon, W. B. Schweizer and F. Diederich, J. Am. Chem. Soc., 2012, 134, 14702.

16 S. Sengupta, M. E. Ibele and A. Sen, Angew. Chem., Int. Ed., 2012, 51, 8434 .

17 K. C.-F. Leung, C.-P. Chak, C.-M. Lo, W.-Y. Wong, S. Xuan and C. H. K. Cheng, Chem. - Asian J., 2009, 4, 364.

18 W. Zhou, Y. J. Guo and D. H. Qu, J. Org. Chem., 2013, 78, 590.

19 S. Sengupta, M. E. Ibele and A. Sen, Angew. Chem., Int. Ed., 2012, 51, 8434.

20 C. S. Vogelsberg and M. A. Garcia-Garibay, Chem. Soc. Rev., 2012, 41, 1892-1910.

21 (a) T. C. Bedard and J. S. Moore, J. Am. Chem. Soc., 1995, 117, 10662; (b) A. Carella, J. Jaud, G. Rapenne and J.-P. Launay, Chem. Commun., 2003, 2434; (c) N. Weibel, A. Mishchenko, T. Wandlowski, M. Neuburger, Y. Leroux and M. Mayor, Eur. J. Org. Chem., 2009, 6140; (d) K. Skopek, M. C. Hershberger and J. A. Gladysz, Coord. Chem. Rev., 2007, 251, 1723.

22 A. Guenet, E. Graf, N. Kyritsakas, L. Allouche and M. W. Hosseini, Chem. Commun., 2007, 2935.

23 A. Guenet, E. Graf, N. Kyritsakas and M. W. Hosseini, Inorg. Chem., 2010, 49, 1872.

24 T. Lang, A. Guenet, E. Graf, N. Kyritsakas and M. W. Hosseini, Chem. Commun., 2010, 46, 3508.

25 A. Guenet, E. Graf, N. Kyritsakas and M. W. Hosseini, Chem. - Eur. J., 2011, 17, 6443.

26 T. Lang, E. Graf, N. Kyritsakas and M. W. Hosseini, Dalton Trans., 2011, 40, 3517.

27 T. Lang, E. Graf, N. Kyritsakas and M. W. Hosseini, Dalton Trans., 2011, 40, 5244.

28 T. Lang, E. Graf, N. Kyritsakas and M. W. Hosseini, Chem. Eur. J., 2012, 18, 10419.

29 T. Lang, E. Graf, N. Kyritsakas and M. W. Hosseini, New J. Chem., 2013, 37, 112.

30 N. Zigon, A. Guenet, E. Graf and M. W. Hosseini, Chem. Commun., 2013, 49, 3637. 
31 N. Zigon, A. Guenet, E. Graf, N. Kyritsakas and M. W. Hosseini, Dalton Trans., 2013, 42, 9740.

32 N. Zigon, N. Kyritsakas and M. W. Hosseini, Dalton Trans., 2013, 43, 152.

33 N. Zigon, P. Larpent, A. Jouaiti, N. Kyritsakas and M. W. Hosseini, Chem. Commun., 2014, 50, 5040.

34 J. K. Kallitsis, K. G. Gravalos, A. Hilberer and G. Hadziioannou, Macromolecules, 1997, 30, 2989.
35 H.-R. Liao, Y.-J. Lin, Y.-M. Chou, F.-T. Luo and B.-C. Wang, J. Lumin., 2008, 128, 1373.

36 L. Larios-López, D. Navarro-Rodríguez, E. M. AriasMarín, I. Moggio, C. V. Reyes-Castañeda, B. Donnio, J. LeMoigne and D. Guillon, Liq. Cryst., 2003, 30, 423.

37 G. M. Sheldrick, Program for Crystal Structure Solution, University of Göttingen, Germany, 1997. 